\title{
Does the Use of Twitter Improve 'Communicative Competence' of Saudi Higher Education Students?
}

\author{
Majed Fahed Alshaibani \\ Media and Communications College, Imam Mohammad Ibn Saud Islamic University, Riyadh, Saudi Arabia
}

\begin{abstract}
The world has seen the emergence of social media, and it has wider implications for all aspects of human life. This has consequently led to the emergence of research on various aspects of life such as knowledge, well-being and emotions. This research looks at how the frequency, quality and duration of Twitter use affect the English language communicative competence of Saudi higher education students. Communicative competence was estimated across four different measures: Linguistic, Discourse, Strategic and Sociolinguistic competence. Data was collected using self-administered questionnaire surveys with students studying in Saudi universities. Data were analysed using regression analysis. This research finds that the use of Twitter has a positive and statistically significant impact on all four aspects of communicative competence of Saudi higher education students.

Keywords: Communicative competence, Twitter and communicative competence, Twitter and language competence, Linguistic competence, discourse competence, strategic language competence, sociolinguistic competence.
\end{abstract}

DOI: $10.7176 / \mathrm{NMMC} / 91-02$

Publication date:June 30th 2020

\section{Introduction}

Social media has affected human lives in a very significant and noticeable way (Moran, Seaman and Tinti-Kane, 2011). Boyd and Ellison (2007) defined social media-based as involving, "(1) constructing a public or semi-public profile within a bounded system, (2) articulating a list of other users with whom participants share a connection, and (3) viewing and traversing their list of connections and those made by others within the system." Since the creation of first social media, six degrees in 1997, several new social media providers have entered the market with Facebook, Twitter, Instagram and Snapchat being some of the most popular names. While social media has eliminated many boundaries separating individuals, one of the key boundaries that still remain when people interact on social media is the language boundary. This boundary continues to affect people's ability to use social media networks. There is a wide distribution in the languages used by Twitter users with only $34 \%$ of Twitter users using English language, 16\% Japanese, 12\% Spanish, $8 \%$ Malay and 6\% Arabic and so on. Despite the wide distribution of languages used, English remains one of the most commonly used languages on Twitter.

Twitter is particularly relevant in the Saudi context because Saudi Arabia is the fastest-growing market for Twitter. According to recent statistics provided by Twitter, the number of monthly active Twitter users in Saudi Arabia is 8.2 million. According to the statistics portal, Statista (2016), at 33\%, Saudi Arabia ranks number one globally in terms of Twitter penetration.

The theory of constructivism states that people construct their own understanding and knowledge of the world, through their interaction with their environment and reflecting on their experiences (Koohang et al., 2009). In this respect, the use of Twitter, which can account for the life experience of many Arabic higher education students, is likely to also affect their learning (Grosseck and Holotescu 2009; Rankin 2009; Ebner et al. 2010; Schroeder et al. 2010). One of the key impacts in this regard is expected to be the knowledge of the English language. Saudi Twitter users tend to most commonly use Arabic and English language on Twitter. It will be interesting to see if the continuous use of Twitter affects their ability to communicate in English. One of the interesting aspects of social media is that while it allows individuals to use a number of languages, but yet the English language remains the dominant language on social media. The growing popularity of social media has significantly increased the popularity of the English language as dominant global language.

The role of technology is significance in language learning (Röver, 2014). The process of communicative language learning and teaching requires proficiency, where the interactions are filled with meaningful context. Technological development has given rise to social media platforms that are significantly used for interpersonal communication. According to Leonardi, Huysman and Steinfield, (2013), social media is a significant platform that promotes social interactions an also function as the important channel through which communication flows. Therefore, social media is of great significance in developing communicative competence. The flow of communication allows students to develop their language skills (Byram, Holmes, and Savvides, 2013). Twitter is considered as the most popular social media tool all over the world. Twitter has also enabled developing academic skills in language learners. Therefore, this paper will look to empirically tests whether the use of Twitter affects the English language communicative competence for non-English speaking Saudi higher education students.

With the growing popularity of Twitter, finding productive uses of Twitter is likely to be very beneficial to 
Saudi society. Such productive uses can be particularly useful for students because most of the active users are students (Junco, Heiberger and Loken, 2010; Junco and Mastrodicasa, 2007; Cotten, 2008). The main objective of this paper is to look at how the use of Twitter affects the ability of Saudi higher education students in communicating in the English language. The main research question was whether the use of Twitter has a positive and noticeable impact on Saudi higher education students' competence in communicating in the English language.

\section{Communicative competence}

The term communicative competence was coined by Dell Hymes in the year 1966 following the introduction of the term 'linguistic competence' by Noam Chomsky's in the year 1965. Communicative competence is understood as intuitive, functional knowledge and control over the principles of using a language. In other words, it could be understood as the knowledge where the learner must use the language in the correct manner (linguistic competence) as well as in the appropriate manner (communicative competence). Communicative competence is a very significant term in language learning that includes the four important elements of language learning. These four important elements are linguistic, discourse, sociolinguistic and strategic competence. Therefore, communicative competence becomes very significant for learning English as a second language or English as a foreign language. Bagarić and Djigunović (2007) explained that communicative competence is made up of two separate words and the combination of these two words means the 'competence of communication' (p. 94). The most significant word is competence, which is commonly applied in the field of linguistics. The linguistic discourse was firstly introduced by Chomsky that provides a significant difference between competence (the knowledge of the monolingual learners) and performance (the use of language in real-life situations). The study of Bagarić and Djigunović(2007) also explains that Hymes has "defined communicative competence not only as an inherent grammatical competence but also as the ability to use grammatical competence in a variety of communicative situations, thus bringing the sociolinguistic perspective into Chomsky's linguistic view of competence" (p. 95). Developing the communicative competence in the students and teaching communicative language provides an authentic opportunity to the learners to go beyond memorising the grammatical elements as well as the social use of the language.

Therefore, communicative competence is a very important term in linguistics that refers to the knowledge of the students related to the grammatical knowledge of the syntax, phonology and morphology of the language, as well as the knowledge related to the social use of language. Therefore, it includes four important elements of language learning: linguistics (knowledge of vocabulary, grammar, punctuations, spellings and syntax) (Mackey, 2014), discourse (knowledge about the pattern of organisation of words, understanding about connecting the ideas and using cohesive and transitional devices) (Schleifer, 2016), (strategic (overcoming the language gaps, ability to modify the text according to purpose and audience, achieving conversational fluency) (Richards, and Schmidt, 2014) and sociolinguistic ( having knowledge and awareness about the social rules of the language, learning nonverbal behaviour and using cultural idioms such as expression and background) (Gandhi, 2014). 


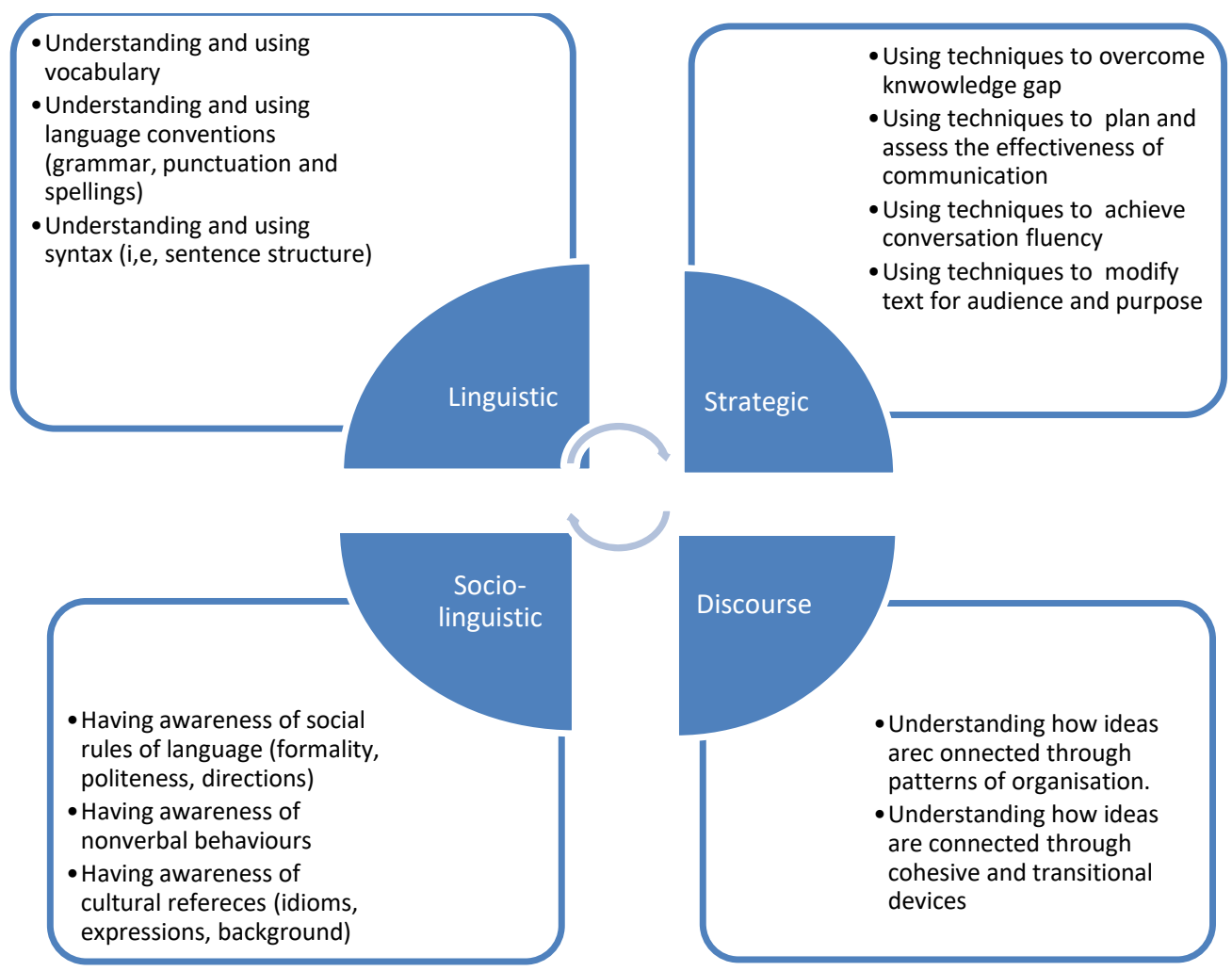

Figure 1: Four components of linguistic competence. Source: Peterwagner (2005)

The four components of communicative competence are significant for foreign language learning and teaching. Therefore, communicative competence becomes very significant in second language learning (LarsenFreeman and Long, 2014). The English language teaching (ELT) is closely associated with linguistics, pragmatics, pedagogy and phonetics. Therefore, non-English speaking students may struggle in second language acquisition. English is the most important and most spoken language all over the world. The education systems of various countries are focusing on improving the educational policies and programs to enhance the use of English and to enhance the English language skills among the students (Kachru, 2006). The mastery of the English language is now considered as the most significant advantage to acquire the employability skills and to become job-ready. English being the most spoken and widely used language, also provide an opportunity to the students for personal development, gaining confidence and achieving career advancement (Kachru, 2006). The educational systems of the world are changing to focus on student-centred learning(Larsen-Freeman and Long, 2014). Therefore, it has been found that communicative competence is very important for second language acquisition (SLA).

In the various colleges and universities, the language teachers and educators are using communicative language learning approach for effective ways of improving the communications skills of the students ((Kamiya, 2006). Chomsky has clearly distinguished between language competence and performance, according to which the learners should be able to judge and understand the grammaticality of the language, which is the main objective of language learning. The sociolinguistic communicative competence given by Hymes is based on "appropriateness of sociocultural significance of an utterance" (Kamiya, 2006, p. 64-65). Therefore understanding the correct grammatical use and being able to use the language in asocial context is significant for achieving communicative competence. For the non-English speaking students, it is important that they learn beyond the traditional way and should be able to speak in actual communicative events. Therefore, communicative language teaching and learning becomes a critical approach that is also highly valued.

The studies have also found that role of teachers and educators are also significant in developing communicative competence in the non-English speaking students. From the traditional teaching and learning styles, the role of teachers has significantly changed and improved. The technology has improved the accessibility of learning resources and learning material. Therefore, the teachers are not required to spend time on providing learning material to the students. Instead, the teachers are mainly required to encourage communication (Byram, Holmes and Savvides, 2013). The role of teachers in teaching English as the second language is to enable students to speak English with fluency and with all the elements of communicative competence. The goals of the students in learning English as the second language is to achieve fluency in a natural and effective manner.

\section{Effect of Social Media on Communicative Competence of Non-English Speaking Students}

There has been a gradual and rapid penetration of technology in modern-day human lives. Education has been a 
significant filed that displayed the growing demand for technology. This is the reason that educational institutions are looking towards ICT for enhancing the knowledge and skills of the students. For example, according to the study of Nut (2010), the government in the United Kingdom is spending a huge amount on the integration of ICT in education. The huge investment in ICT displays its significance in teaching and learning. Since communication is the cornerstone in the field of language learning, the scholars and researchers are working towards finding innovative tools and platforms for language learning in the changing dynamics of the classrooms (McKeeman, and Oviedo, 2013). This displays that technology and social media play a significant role in developing the communicative competence of non-English speaking students.

McKeeman and Oviedo (2013) asserted that the four important skills of the $21^{\text {st }}$ century are communication, collaboration, creativity and critical thinking. These skills can be enhanced with the use of digital technology or various other technological tools. Technology also plays a significant role in education and language learning. The integration of technology in English learning classrooms has become imperative (Buabeng-Andoh, 2012). The integration of ICT in teaching and learning English has been a significant topic of debate among scholars and researchers. It is because; technology has the potential to produce the skilled, competitive, technologically literate and communicatively competent workforce (Light, and McNaughton, 2014). The ESL (English as a second language) and EFL (English as a foreign language) learners often display poor communication skills and lack of proficiency, because of two significant aspects. The first is the lack of appropriate motivation from the teachers, and the second is the inability to enhance their skills through communication in real situations (Buabeng-Andoh, 2012). Therefore, the traditional classroom learning in EFL and ESL could not achieve the language competency among the students, because they lack approaches of motivation and providing an environment where students can communicate and interact.

Social media are likely to affect the communicative competence of non-English speaking students because it provides the interactive and communicative platform that helps in enhancing the personal as well as the language skills of the students. Social media provides real situations to the students to communicate and learn. Social media is also significant as it promotes collaborative learning. For developing communicative competence, the individual requires sufficient knowledge, skills, critical thinking and judgment. Social media provides the platform to the learners, where they can gain knowledge, enhance their skills through interactions, use critical thinking skills in construction and organisation of words and judgment can help them to use language appropriately (ChinchillaGálvez, 2016). Social media provides the opportunity for writing, speaking, reading and listening, and many other communicative activities like games, videos, drama etc. Such elements provide a realistic and contextual way of learning a language. However, the traditional classrooms tend to neglect the many important aspects of communication in language learning, and focus of the students and teachers is mainly on clearing the examinations (Musa, Lie, and Azman, 2012). For language learning, the lack of communicative approach can impact the communicative competency of the students and students would not be able to achieve proficiency over the language.

Social media platforms allow learners to learn new words and enhance their vocabulary. Web 2.0 technologies can have a significant impact on the communicative competency of the students. The language teachers are significantly focusing on instructing the students about using proper grammar, pronunciation and intonations and also cultural distinctions so that students can be able to communicate in the target language. The premise of communication has not changed, but with the integration of social media, the process of communication has changed. The new social media platforms and applications are helping students to enhance their English learning skills. ?The most important thing is that generation entering the English language learning classrooms is changing, and the millennial generation is specifically craving for 24/7 connectivity and collaborative learning environment. The current generation is also considered as the digital natives that have grown with technology. Therefore technology has a significant impact on every aspect of the life of students.

The social media conversations surrounded by the collaborative virtual environment are embedded with various kinds of multimedia tools (texts, images, videos, audios and documents). The language teachers have limited time in the classrooms to spend with students, but social media platforms provide the opportunity to the teachers to stay in contact with the teachers and to have a continuous check on the skills and performance of the students. The social media platforms also provide the opportunity of enhancing language learning outside the classrooms, simultaneously enhancing language interaction (McKeeman, 2012). The multimodal and multimedia nature of the social media tools is significant in enhancing multiple language learning and communicative intelligence of the students. Some of the other benefits of the social media in enhancing communicative competence of the non-English speaking students is proving real-time experience, ability to achieve the immediate audience response, the response of teachers and peers, and finding new information instantly (Griesemer, 2012). The social media tools like Facebook and Twitter also allow students to gather live responses on their assignments, presentations and written works that help to improve their communicative competency. Social media provides the videos, educational links communicative applications, through which, students can apply the communicative, collaborative and critical thinking in enhancing their vocabulary and the use of language in the social context 
(Griesemer, 2012).

\section{Conceptual framework}

The framework used in this paper tests the following hypothesis.

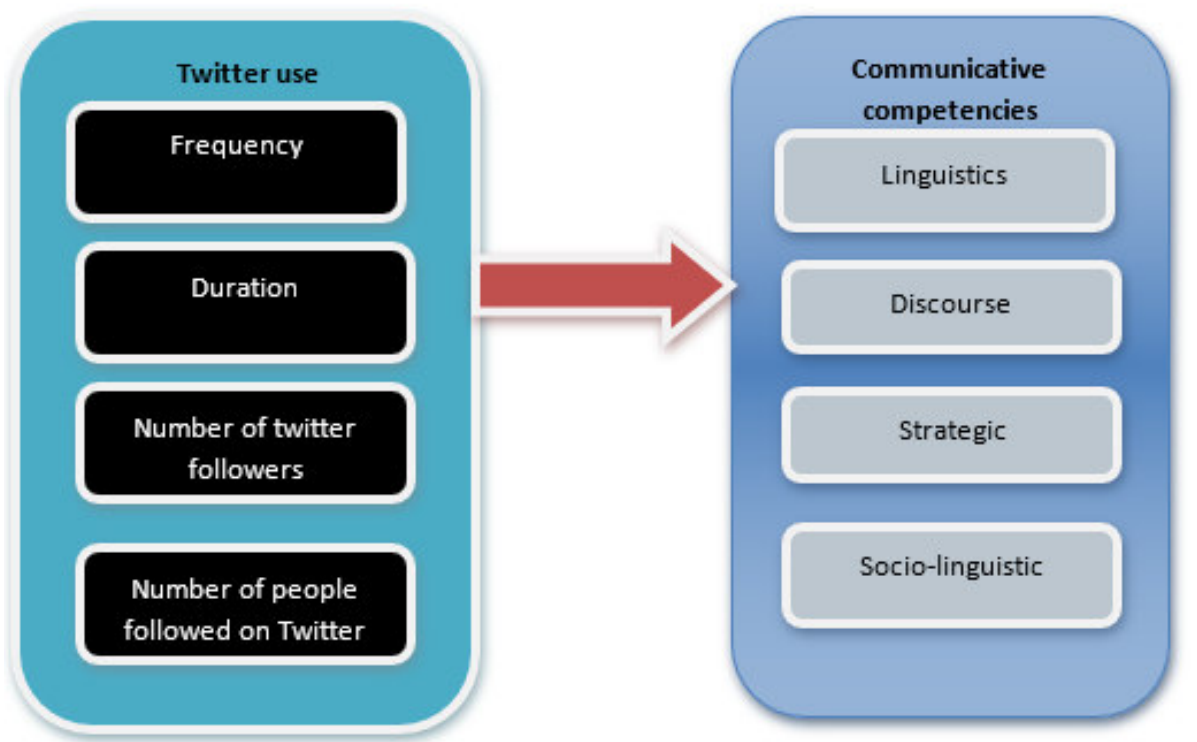

Figure 2: Conceptual framework

$\mathrm{H}_{1}$ : Use of Twitter affects the Linguistics component (knowledge of vocabulary, grammar, punctuations, spellings and syntax) of communicative competencies.

$\mathrm{H}_{2}$ : Use of Twitter affects the Discourse component (knowledge about the pattern of organisation of words, understanding about connecting the ideas, and using cohesive and transitional devices) of communicative competencies.

$\mathrm{H}_{3}$ : Use of Twitter affects the Strategic component (overcoming the language gaps, ability to modify the text according to purpose and audience, achieving conversational fluency) of communicative competencies.

$\mathrm{H}_{4}$ : Use of Twitter affects the Sociolinguistic component (having knowledge and awareness about the social rules of the language, learning non-verbal behaviour and using cultural idioms such as expression and background) of communicative competencies.

\section{Methodology}

5.1 Research design

This is quantitative research based on positivist philosophy and objectivist ontology. The purpose of this research is to empirically test whether the use of Twitter leads to improvement in Saudi higher education students' English language communicative competence. Using positivist epistemology will help us in generalising whether there are concrete and verifiable links between twitter use and improvement in Saudi higher education students' English language communicative competence.

\subsection{Research instruments and data gathering procedure}

Data was collected from higher education students studying in Saudi Arabian Universities using a questionnaire survey. In terms of the use of Twitter, three aspects of use were mainly focused upon:

- Frequency of use (how often the user uses Twitter);

- $\quad$ Duration of use (for how long the user have been using Twitter);

- Quality (How many followers do the user have and how many people does he/she follow on twitter).

Structure of the questionnaire was as follows 
Table 1: Questionnaire structure

\begin{tabular}{|l|c|}
\hline \multicolumn{1}{|c|}{ Item } & Number of questions \\
\hline Gender & 1 \\
\hline Age & 1 \\
\hline Education level: Current level of study & 1 \\
\hline Twitter use: Frequency & 3 \\
\hline Twitter use: Duration & 1 \\
\hline Twitter use: Quality & 3 \\
\hline Communicative competence: Linguistic & 4 \\
\hline Communicative competence: Discourse & 3 \\
\hline Communicative competence: Strategic & 3 \\
\hline Communicative competence: Socio-linguistic & 5 \\
\hline
\end{tabular}

In total, the questionnaire consisted of 25 questions. A questionnaire survey was conducted between March 2017 and May 2017.

One of the issues with questionnaire surveys is self-reported bias. Due to a lack of a concrete measure of assessing people's communicative competence, self-reported evaluation of communicative competence was considered useful. There is a likelihood that respondents may have misevaluated or misreported their communicative competence or may have miscalculated the impact of Twitter on their communicative competence. However, due to several privacy, ethical and other concerns, it was not possible for the author to collect observational data. Furthermore, observational data would have been incomplete because the author could not have collected data on tweets that users only read but do not respond to in any way. Also, such data would have to be collected over a long time period in order to see any noticeable impact on English language communicative competence. Due to these reasons, self-administered questionnaires, despite their self-reporting bias, were selected for this study.

\subsection{Sampling}

The sample for this study included individuals who are:

- Higher education students from Saudi Arabia who are in the final year of their Bachelor's studies or at levels higher than that. This is to make sure that they qualified as higher education students at last two years ago when they were using Twitter.

- Who has been using Twitter for at least the last two years? This is to make sure that people can track a long-term impact of using Twitter on their English communicative competence

- Individuals who have never studied outside Saudi Arabia. This is to minimise the likely impact of other variables on English communicative competence, such as the experience of day to day use of English.

- Who post at least some tweets in English. This is to ensure that the respondents can provide some useful data.

Respondents were identified using the Twitter platform. The researcher identified respondents based on the criteria stated above. In total, 1934 individuals were contacted requesting participation in the survey. Out of this, 602 agreed to participate in the survey. The questionnaire was posted online, and the link was e-mailed to the individuals who consented to participate in the study. Two reminder e-mails were sent to the individuals to complete the survey. However, only 378 actually responded to the survey.

\subsection{Data analysis technique}

Descriptive analysis and ANOVA tests were conducted using SPSS. Regression analysis was used to whether there is a statistically significant causal relationship between the use of Twitter and the communicative competence of users.

\section{Data Analysis}

\subsection{Comparison of means}

$58 \%$ of the respondents were male, and $42 \%$ were female. This means that the sample comprised of more men than women. In order to evaluate the impact of such a distribution, the T-test was conducted to compare the means of responses submitted by men and women. The table below summarises the results of the t-test: 
Table 2: Summary of T-test results

\begin{tabular}{|c|c|c|c|}
\hline Variable & Gender & Mean & p-value \\
\hline \multirow[t]{2}{*}{ Twitter use: Frequency } & Male & 3.81 & \multirow{2}{*}{0.041} \\
\hline & Female & 3.21 & \\
\hline \multirow[t]{2}{*}{ Twitter use: Duration } & Male & 3.74 & \multirow{2}{*}{0.068} \\
\hline & Female & 3.62 & \\
\hline \multirow[t]{2}{*}{ Twitter use: Quality } & Male & 4.11 & \multirow{2}{*}{0.087} \\
\hline & Female & 3.87 & \\
\hline \multirow[t]{2}{*}{ Communicative competence: Linguistic } & Male & 3.22 & \multirow{2}{*}{0.066} \\
\hline & Female & 3.46 & \\
\hline \multirow[t]{2}{*}{ Communicative competence: Discourse } & Male & 3.38 & \multirow{2}{*}{0.102} \\
\hline & Female & 3.42 & \\
\hline \multirow[t]{2}{*}{ Communicative competence: Strategic } & Male & 3.43 & \multirow{2}{*}{0.094} \\
\hline & Female & 3.31 & \\
\hline \multirow[t]{2}{*}{ Communicative competence: Sociolinguistic } & Male & 3.51 & \multirow{2}{*}{0.179} \\
\hline & Female & 3.49 & \\
\hline
\end{tabular}

Responses indicate that for most of the variables, there is no statistically significant difference between the responses given by men and women except for the frequency of twitter use. Responses clarify that men are more frequent users of Twitter as compared to females.

The charts below show the distribution of respondents by age group and education level

Table 3: Distribution of respondents by age group and education level

\begin{tabular}{|c|c|c|c|}
\hline Age group & $\%$ of respondents & The current level of education & $\%$ of respondents \\
\hline Over 18 - under 21 & $6 \%$ & Higher Diploma & $4 \%$ \\
\hline Over 21- under 25 & $29 \%$ & Bachelor's & $35 \%$ \\
\hline Over 25 - under 35 & $47 \%$ & Master's & $42 \%$ \\
\hline Over 35- under 45 & $16 \%$ & $\mathrm{PhD}$ & $19 \%$ \\
\hline Over 45 & $2 \%$ & Other & $0 \%$ \\
\hline
\end{tabular}

Responses indicate that most of the respondents were from the 25-35 age group and were pursuing their Masters, followed by people from the 21-25 age group and those pursuing their Bachelor's degree. This means that the sample had a high proportion of young respondents. This was expected because this paper focused on higher education students who are currently.

\subsection{Correlation analysis}

The correlation test is a statistical analysis used to shed light on the force and trend of a linear relationship between two variables (Pallant, 2001). It is the level to which the correlation is utilised to identify the significance and strength of the relationships of the variables. In this study, the Pearson correlation coefficient (r) was used for the evaluation of such a correlation. According to Cohen (2013), correlation analysis describes the intensity and extent of two variables correlation. The table below shows the correlation coefficient for a different set of variables: 
Table 4: Correlation statistics

\begin{tabular}{|l|c|l|l|}
\hline Variables & Correlation coefficient & Sig & Strength of relationship \\
\hline Twitter use- Communicative competence & 0.517 & 0.012 & Strong \\
\hline Twitter use- Linguistic & 0.446 & 0.027 & Moderate \\
\hline Twitter use- Discourse & 0.529 & 0.000 & Strong \\
\hline Twitter use- Strategic & 0.398 & 0.043 & Moderate \\
\hline Twitter use- Socio-linguistics & 0.483 & 0.039 & Moderate \\
\hline
\end{tabular}

\subsection{Data testing}

Before regression analysis can be conducted it is essential to test the data for certain assumptions such normality, linearity, and independence of error terms (Tatham et al. 2006; Sekaran \& Bougie, 2006; Sekaran, 2006). The table below summarises the outputs of different tests conducted to tests the assumptions essential to test the suitability of data for regression analysis.

Table 5: Normality test results

\begin{tabular}{|c|c|c|c|c|}
\hline Variables conducted & Statistic used & Statistical output & Acceptable value & Test outcome \\
\hline \multicolumn{5}{|c|}{$\begin{array}{c}\text { Test for Normality } \\
\end{array}$} \\
\hline \multirow[t]{2}{*}{ Twitter use } & Skewness & 0.881 & Between 2 and -2 & Accepted \\
\hline & Kurtosis & 1.01 & Between 2 and -2 & Accepted \\
\hline \multirow{2}{*}{$\begin{array}{c}\text { Communicative competence: } \\
\text { Linguistic }\end{array}$} & Skewness & 0.338 & Between 2 and -2 & Accepted \\
\hline & Kurtosis & 0.419 & Between 2 and -2 & Accepted \\
\hline \multirow{2}{*}{$\begin{array}{l}\text { Communicative competence: } \\
\text { Discourse }\end{array}$} & Skewness & 0.173 & Between 2 and -2 & Accepted \\
\hline & Kurtosis & 0.286 & Between 2 and -2 & Accepted \\
\hline \multirow{2}{*}{$\begin{array}{l}\text { Communicative competence: } \\
\text { Strategic } \\
\end{array}$} & Skewness & -0.53 & Between 2 and -2 & Accepted \\
\hline & Kurtosis & -0.47 & Between 2 and -2 & Accepted \\
\hline \multirow{2}{*}{$\begin{array}{l}\text { Communicative competence: } \\
\text { Socio-linguistic } \\
\end{array}$} & Skewness & 0.293 & Between 2 and -2 & Accepted \\
\hline & Kurtosis & 0.202 & Between 2 and -2 & Accepted \\
\hline \multicolumn{5}{|c|}{ Test for Independence of Error Term } \\
\hline $\begin{array}{l}\text { Twitter use- Communicative } \\
\text { competence }\end{array}$ & Durbin Watson & 1.637 & Between 1.5 and 2.5 & Accepted \\
\hline Twitter use- Linguistic & Durbin Watson & 1.717 & Between 1.5 and 2.5 & Accepted \\
\hline Twitter use- Discourse & Durbin Watson & 1.518 & Between 1.5 and 2.5 & Accepted \\
\hline Twitter use- Strategic & Durbin Watson & 1.902 & Between 1.5 and 2.5 & Accepted \\
\hline Twitter use- Sociolinguistic & Durbin Watson & 1.833 & Between 1.5 and 2.5 & Accepted \\
\hline
\end{tabular}

The table above indicates that the data satisfied the tests for normality and independence of error terms. In addition, the correlation between any of the variables was not too high.

6.4 Regression analysis

Following the confirmation of the assumptions required for conducting a regression analysis, simple linear regression tests were conducted. The table below summarises the results of the regression analysis 
Table 6: Regression test results

\begin{tabular}{|c|c|c|c|c|c|}
\hline $\begin{array}{c}\text { Dependent } \\
\text { variable }\end{array}$ & Independent variables & $\begin{array}{l}\text { Unstandard } \\
\text { ised beta } \\
\text { coefficient }\end{array}$ & $\begin{array}{l}\text { Adj R- } \\
\text { squared }\end{array}$ & T-stat & p-value \\
\hline \multirow{4}{*}{$\begin{array}{l}\text { Communicative } \\
\text { competence - } \\
\text { Linguistics }\end{array}$} & Frequency of Twitter use & 0.409 & \multirow{4}{*}{0.441} & 11.685 & $0.022 * *$ \\
\hline & Duration of Twitter use & 0.286 & & 9.733 & $0.013^{* *}$ \\
\hline & Number of Twitter followers & 0.155 & & 4.502 & $0.021 * *$ \\
\hline & Number of people followed on Twitter & 0.311 & & 8.853 & $0.000^{* * *}$ \\
\hline \multirow{4}{*}{$\begin{array}{l}\text { Communicative } \\
\text { competence- } \\
\text { Discourse }\end{array}$} & Frequency of Twitter use & 1.158 & \multirow{4}{*}{0.381} & 5.734 & $0.013^{* *}$ \\
\hline & Duration of Twitter use & 0.627 & & 2.142 & $0.047^{* *}$ \\
\hline & Number of Twitter followers & 0.629 & & 1.219 & 0.179 \\
\hline & Number of people followed on Twitter & 0.448 & & 4.186 & $0.031^{* *}$ \\
\hline \multirow{4}{*}{$\begin{array}{c}\text { Communicative } \\
\text { competence - } \\
\text { Strategy }\end{array}$} & Frequency of Twitter use & 0.024 & \multirow{4}{*}{0.298} & 0.893 & 0.372 \\
\hline & Duration of Twitter use & 0.64 & & 34.723 & $0.000^{* * *}$ \\
\hline & Number of Twitter followers & 0.012 & & 1.129 & 0.259 \\
\hline & Number of people followed on Twitter & 0.4 & & 1.601 & 0.110 \\
\hline \multirow{4}{*}{$\begin{array}{c}\text { Communicative } \\
\text { competence - } \\
\text { Socio- } \\
\text { Linguistics }\end{array}$} & Frequency of Twitter use & 0.849 & \multirow{4}{*}{0.529} & 6.889 & $0.000^{* * *}$ \\
\hline & Duration of Twitter use & 0.438 & & 4.769 & $0.003^{* *}$ \\
\hline & Number of Twitter followers & 0.383 & & 1.642 & 0.102 \\
\hline & Number of people followed on Twitter & 1.003 & & 2.694 & $0.046^{* *}$ \\
\hline
\end{tabular}

Note. ${ }^{* *} \mathrm{p}<0.05, * * * \mathrm{p}<0.001$.

The table below summarises the regression tests in terms of the relationships identified:

Table 7: Hypothesis test results

\begin{tabular}{|l|l|l|l|l|}
\hline Variables & $\begin{array}{l}\text { Twitter use- } \\
\text { frequency }\end{array}$ & $\begin{array}{l}\text { Twitter } \\
\text { use- } \\
\text { duration }\end{array}$ & $\begin{array}{l}\text { Twitter use - } \\
\text { number of } \\
\text { followers }\end{array}$ & $\begin{array}{l}\text { Twitter use - } \\
\text { number of people } \\
\text { followed }\end{array}$ \\
\hline Twitter use- Linguistic & $\checkmark$ & & & \\
\hline Twitter use- Discourse & $\checkmark$ & & $\mathbf{X}$ & \\
\hline Twitter use- Strategic & $\mathbf{X}$ & $\mathbf{X}$ & & $\mathbf{X}$ \\
\hline Twitter use- Socio-linguistic & $\checkmark$ & $\checkmark$ & $\mathbf{X}$ & \\
\hline
\end{tabular}

\section{Findings}

The results above indicate that on most counts use of Twitter will have a significant impact on communicative competencies of Saudi higher education students. All four aspects of Twitter use were found to have a positive and significant impact on Linguistic competencies of Saudi higher education students. On the other hand, only 'number of followers on twitter' seems to have a statistically significant relationship with the 'Strategic' aspect of communicative competency. Strategic competence requires the ability to achieve conversational fluency and the ability to modify text for audience and purpose. At the same time, the number of followers on Twitter was found not to have any statistically significant impact on Discourse and Sociolinguistic aspects of communicative competence.

\section{Discussion}

People are getting involved with technology, more and more every day. Students all over the world use various kinds of blogs and forums as the source of communication and interaction. Twitter is the most popular microblogging application, which allows users to use short messages as the source of communication (Harmandaoglu, 2012). The students, all over the world, are actively using Twitter for communicating with peers from around the world. The government of the developed nations and developing nations are also focusing on integrating Twitter in education. "Twitter is the most popular microblogging application, with almost one million users, called twitterers, who can send and receive messages via the web, SMS, instant message clients, and by third-party applications" (Grosseck and Holotescu, 2008, p. 1). The significance of Twitter is very high in education because it can be used by the teachers and students even outside the classrooms.

This study supports the findings of Borau et al. (2009). According to the study of Borau et al. (2009), "one aspect of language learning which can be practiced in Twitter is communicative competence, a concept based on a view of language learning postulated in the communicative approach to language teaching, in which interaction is focused as a means of language learning and teaching" (p. 81). The current view towards language learning mainly emphasises on communicative competence. Twitter allows enhancing the entire four elements or components of communicative competence (grammatical competence, discourse competence, sociolinguistic 
competence and strategic competence) (Borau et al., 2009).

This research confirms that use of Twitter affects linguist aspect of communicative competency. With the help of microblogging facilitated by Twitter, students can interact and communicate with people all over the world. Twitter provides the word limit of 140 words to write the blog, which helps in improving the sentence construction, vocabulary and organisation of words.

This research finds that some, if not all, aspects of Twitter use have a statistically significant impact on each aspect of communicative competence of Saudi higher education students. The twitter posts that are also called as tweets are limited to 140 characters that include characters, spaces, punctuations and syntax. Therefore, the language learners have to focus on the content, organisation, vocabulary, spellings, purpose, pronunciation and mechanics. The students are also required to concentrate on the accuracy of the words used and required to achieve communicative precision (Ahmad, 2015). One of the important aspects of communicative competency is sociolinguistic competency. Twitter allows users to interact with other users from around the world on a range of topics. Cheng (2012) explains that Twitter provides the opportunity for social engagement and social involvement that displays great potential and facilitator of English language learning. The quick and spontaneous responses on Twitter help in enhancing the reading and writing skills of the students. Reading and writing are a very significant part of developing communicative competence (Ahmad, 2015). Since Twitter is very popular with young people and students, this social media tool can be effectively integrated into education and language learning (Malki, 2015). Micro-blogging facilitated by Twitter makes the communication process faster and allow the students to express their ideas and thoughts. The students get the opportunity to express and interact in English, as English is the dominating language on social media (Holotescu, and Grosseck, 2010). With this interaction in English, students can learn new words and also understand the social use of language. Therefore, communicative competence among the students is developed through Twitter.

One significant aspect of Twitter is that it helps in the sense of community that enhances social coherence. The sense of community is also important for developing the personal learning networks, through which students interact, learn, read, speak and write in a meaningful manner that increases their communicative competence (Lowe, 2016).

Twitter is very popular among the students and young people because it provides the interesting opportunity of tracking the interest of the fellow tweeters and read various tweets. Twitter enhances the focus of the users and enhances their capability for "clever use of language" (Asur and Huberman, 2010). Studies have also shown that students have a positive attitude towards the use of Twitter and find it an easier way to communicate in the target language (Borau et al., 2009). Twitter also allows brainstorming and group discussions in the target language that enhance their capability of using the language. The online communication on Twitter can be facilitated by the help of teachers through which student engagement can be promoted. Twitters also allow written communication that can be easily monitored by the instructor (Gao, Luo, and Zhang, 2012). The instant feedback of the teachers on the written tweets of the students can help them to understand their mistakes and practical way of learning. The virtual environment keeps student connected with other people and communities, and student can interact with other English speaking people (Gao, Luo, and Zhang, 2012). Therefore, twitter also enhances the communicative functioning. This is the reason that Twitter is significant in stimulating communicative competence for the target language. Twitter provides the asynchronous communication platform, and quick response allows students to indulge in collaborative learning (Cheng, 2012). Twitter helps in promoting more in-depth discussions and also encourages the chance of effective interpersonal relationships (Malki, 2015). Therefore, the interactive functionality of Twitter is very significant in promoting communicative competence in non-English speaking students.

\section{Conclusion}

Role of social media is very important in modern society. Social media is a very popular topic among the researchers and policymakers for its successful integration in education. Learning English as a second language or as a foreign language has also become very important in non-English speaking countries because English is the most significantly used language that also defines social status. Using social media for learning English can be very important and effective. The findings from the literature suggest that social media is very effective in improving the academic skills and language learning skills of students. Communicative competence is the most important skill that must be developed in the students. Paper concludes that Twitter is very effective in enhancing the communicative competence among the non-English speaking students. Twitter provides many opportunities for interaction and communication through which students can easily learn all the elements of communicative competence. Twitter has the potential to replace all the other social media tools, as it has simplified the process of learning English in an innovative and effective manner.

\section{References}

Ahmad, M. (2015), “The Effect of Twitter on Developing Writing Skill in English as a Foreign Language”, Arab 
World English Journal, Special Issue on CALL No.2 July, 2015. Available [online] at SSRN: https://ssrn.com/abstract $=2843985$

Asur, S. and Huberman, B.A. (2010), "Predicting the future with social media". In Web Intelligence and Intelligent Agent Technology (WI-IAT), 2010 IEEE/WIC/ACM International Conference on (Vol. 1, pp. 492-499).IEEE.

Bagarić, V. and Djigunović, J.M. (2007), "Defining communicative competence”, Metodika, 8(1), pp.94-103.

Borau, K., Ullrich, C., Feng, J. and Shen, R. (2009) "Microblogging for language learning: Using twitter to train communicative and cultural competence", Advances in web-based learning-ICWL 2009, pp.78-87.

Buabeng-Andoh, C. (2012) "Factors influencing teachers' adoption and integration of information and communication technology into teaching: A review of the literature", International Journal of Education and Development using Information and Communication Technology, 8(1), p.136.

Byram, M., Holmes, P. and Savvides, N. (2013) "Intercultural communicative competence in foreign language education: Questions of theory, practice and research", The Language Learning Journal, 41(3), pp.251-253.

Cheng, H.Y. (2012), “Applying Twitter to EFL reading and writing in a Taiwanese college setting”, Doctoral dissertation, Indiana State University.

Chinchilla-Gálvez, A. (2016), “The cultural component in the English language classroom”, Londinium.

Cotten S.R. (2008), "Students' technology use and the impacts on well-being”, In Using Emerging Technologies to Enhance Student Engagement.New Directions for Student Services Issue \#124 (eds R. Junco \& D.M. Timm), pp. 55-70.Jossey-Bass, San Francisco, CA.

Ebner M., Lienhardt C., Rohs M. and Meyer I. (2010), "Microblogs in higher education - a chance to facilitate informal and process-oriented learning", Computers \& Education 55, pp. 92-100.

Gao, F., Luo, T. and Zhang, K. (2012) "Tweeting for learning: A critical analysis of research on microblogging in education published in 2008-2011”, British Journal of Educational Technology, 43(5), pp.783-801.

Gandhi, M. (2014), "Interaction competence in a communication event: A sociolinguistic perspective", The Business \& Management Review, 5(2), p.223.

Griesemer, J.A. (2012), “Using social media to enhance students' learning experiences", Quality approaches in higher education, 3(1), pp.8-11.

Grosseck G. and Holotescu C. (2009), "Can we use Twitter for educational activities?" Proceedings of the 4th International Scientific Conference: eLearning and Software for Education, Bucharest, Romania. Available[online] at: http://adlunap.ro/eLSE_publications/papers/2008/015.-697.1.Grosseck\%20GabrielaCan\%20we\%20use.pdf.[Last accessed in 28/08/2017].

Harmandaoglu, E. (2012), "The use of Twitter in language learning and teaching", In International Conference: ICT for Language Learning, 5th edition. Retrieved from http://conference.pixel-online. net/ICT4LL2012/common/download/Paper pdf/211-IBT41-FP-Harmandaoglu-ICT2012. pdf.

Holotescu, C. and Grosseck, G. (2010), "Learning to microblog and microblogging to learn. A case study on learning scenarios in a microblogging context", In The 6th International Scientific Conference eLearning and Software for Education Bucharest (pp. 15-16). Bucharest: Romania.

Junco, R., Heibergert, G. and Loken, E. (2010), "The effect of Twitter on college student engagement and grades", Journal of Computer Assisted Learning, 27(2), April 2011, pp. 119-132

Junco R. and Mastrodicasa J. (2007), "Connecting to the Next Generation: What Higher Education Professionals Need to Know about Today's Students”, NASPA, Washington, DC.

Kamiya, M. (2006), "The role of communicative competence in L2 learning", Sophia Junior College Faculty Bulletin, 26, pp.63-87.

Kachru, B.B. (2006), "The English language in the outer circle”, World Englishes, 3, pp.241-255.

Koohang, A., Riley, L. and T. Smith (2009), "E-Learning and Constructivism: From Theory to Application", Interdisciplinary Journal of E-Learning and Learning Objects, 5(2009), pp. 91-109

Larsen-Freeman, D. and Long, M.H. (2014), "An introduction to second language acquisition research", Routledge.

Leonardi, P.M., Huysman, M. and Steinfield, C. (2013), "Enterprise social media: Definition, history, and prospects for the study of social technologies in organisations", Journal of Computer-Mediated Communication, 19(1), pp.1-19.

Light, J. and McNaughton, D. (2014), "Communicative competence for individuals who require augmentative and alternative communication: A new definition for a new era of communication?", Taylor\& Francis.

Lowe, R.E.M. (2016), "Education All 'Twitter: Twitter's Role in Educational Technology", Marshall University.

Mackey, A. (2014), “Applying Intercultural Linguistic Competence to Foreign Language Teaching and Learning”, International Burch University.

Malki, Z. (2015), "Twitter as a Social Network in Academic Environments for Exchanging Information Taibah University: A Case Study", International Journal of Information Technology and Computer Science (IJITCS), 7(10), p.15.

Matney M. and Borland K. (2009), "Facebook, blogs, tweets: How staff and units can use social networking to 
enhance student learning", Presentation at the annual meeting of the National Association of Student Personnel Administrators, Seattle, WA.

McKeeman, L. and Oviedo, B. (2013), "Enhancing communicative competence through integrating 21st-century skills and tools", 2013 CSCTFL Report, pp.39-54.

McKeeman, L. (2012), "In the classroom: Using VoiceThread to engage and enhance language learning", The Language Educator, 7, pp.54-57.

Moran, M., Seaman, J., and Tinti-Kane, H. (2011), "Teaching, learning, and sharing: how today's higher education faculty use social media", Pearson Learning Solutions, the Babson Survey Research Group, and Converseon Research Report, Available[online] at:http://www.pearsonlearningsolutions.com/educators/pearson-social-media-survey-2011-bw.pdf .[Last accessed in 28/08/2017].

Musa, N.C., Lie, K.Y. and Azman, H. (2012), "Investigating academic literacy practices in English language: The case of Malaysia”, In International Conference: Innovative Research in a Changing and Challenging World, May (pp. 16-18).

Nut, J. (2010), "Professional educators and the evolving role of ICT in schools", Perspective report. Available[online] at: http://www. ictliteracy. info/rf. pdf/ICTinSchools. pdf.[Last accessed in 28/08/2017].

Peterwagner, R. (2005), "What is the Matter with Communicative Competence? An Analysis to Encourage teachers of English to assess the very basis of their teaching”, LIT Verlag Münster.

Rankin M. (2009), "Some general comments on the 'Twitter experiment", Web post by Monica Rankin. Available[online] at: http://www.utdallas.edu/ mrankin/usweb/twitterconclusions.htm [Last accessed in 25/08/2017].

Richards, J.C. and Schmidt, R.W. (2014), “Language and communication”, Routledge.

Röver, C. (2014), "Testing ESL pragmatics: Development and validation of a web-based assessment battery", Peter Lang.

Schleifer, R. (2016), "AJ Greimas and the nature of meaning: linguistics, semiotics and discourse theory", Routledge.

Schroeder A., Minocha S. and Schneider C. (2010), "The strengths, weaknesses, opportunities, and threats of using social software in higher and further education teaching and learning" Journal of Computer Assisted Learning, 26, pp. 159-174.

Sekaran, U., and Bougie, R. (2006), "Research methods for business: A skill building approach", (5th ed.). John Wiley and Sons, Chichester.

Sekaran, U. (2006), "Research Methods for Business: A Skill Building Approach”, (1st ed.). Wiley India Pvt.

Tatham, R. L., Anderson, R. E., and Black, B. (2006), "Multivariate data analysis", (5th ed.).Academic Internet Publication, Moorpark, CA. 
Appendix: Questionnaire

\begin{tabular}{|c|c|c|c|c|}
\hline \multicolumn{5}{|c|}{ What is your gender } \\
\hline \multicolumn{2}{|c|}{ Male } & \multicolumn{3}{|c|}{ Female } \\
\hline & & hat is your age grou & & \\
\hline Over 18 - under 21 & Over 21- under 25 & Over 25 - under 35 & Over 35 - under 45 & Over 45 \\
\hline \multicolumn{5}{|c|}{ What is your education level: Current level of study } \\
\hline Higher Diploma & Bachelor's & Master's & $\mathrm{PhD}$ & Other \\
\hline \multicolumn{5}{|c|}{ How often do you access Twitter } \\
\hline $\begin{array}{c}\text { Several times per } \\
\text { day }\end{array}$ & Once a day & $\begin{array}{c}\text { Once every few } \\
\text { days }\end{array}$ & Once a week & Occasionally \\
\hline
\end{tabular}

\begin{tabular}{|c|c|c|c|c|}
\hline \multicolumn{5}{c}{ How often do you post something on Twitter } \\
\hline $\begin{array}{c}\text { Several times per } \\
\text { day }\end{array}$ & Once a day & $\begin{array}{c}\text { Once every few } \\
\text { days }\end{array}$ & Once a week & Occasionally \\
\hline \multicolumn{5}{|c|}{ How much time do you spend on Twitter } \\
\hline $\begin{array}{c}\text { Several hours per } \\
\text { day }\end{array}$ & $\begin{array}{c}\text { Few minutes per } \\
\text { day }\end{array}$ & $\begin{array}{c}\text { Few minutes every } \\
\text { few days }\end{array}$ & Few minutes a month & $\begin{array}{c}\text { Very little time } \\
\text { occasionally }\end{array}$ \\
\hline
\end{tabular}

\begin{tabular}{|c|c|c|c|c|}
\hline \multicolumn{5}{|c|}{ How many people do you follow on twitter? } \\
\hline$<5$ & Between 5-50 & Between 51-1000 & Between 1001-10000 & $>10000$ \\
\hline \multicolumn{7}{|c|}{ How many people follow you on Twitter? } \\
\hline$<5$ & Between 5-50 & Between 51-1000 & Between 1001-10000 & $>10000$ \\
\hline \multicolumn{7}{|c|}{ How many Tweets have you posted within last one month? } \\
\hline & Between 6 and 25 & Between 26 and 100 & between 101 and 500 & More than 500 \\
\hline \multicolumn{5}{|c|}{ Linguistic- Using Twitter has significantly improved my English vocabulary } \\
\hline
\end{tabular}

\begin{tabular}{|c|c|c|c|c|}
\hline Definitely & Yes & Cannot say & No & Definitely not \\
\hline \multicolumn{5}{|c|}{ Linguistic- Twitter use has allowed me better at English grammar } \\
\hline Definitely & Yes & Cannot say & No & Definitely not \\
\hline \multicolumn{5}{|c|}{ Linguistic-Due to Twitter use I understand the use of punctuation in the English language } \\
\hline Definitely & Yes & Cannot say & No & Definitely not \\
\hline
\end{tabular}

Linguistic- Twitter has given me the knowledge to form correct and understandable sentences in the English language

\begin{tabular}{|l|l|l|l|l|}
\hline Definitely & Yes & Cannot say & No & Definitely not \\
\hline
\end{tabular} Discourse- Due to the use of Twitter I understand how ideas are connected through different patterns of organisation

\begin{tabular}{|c|c|c|c|c|}
\hline Definitely & Yes & Cannot say & No & Definite \\
\hline \multicolumn{5}{|c|}{ Discourse- Understand how ideas are connected through cohesive and transitional devices } \\
\hline Definitely & Yes & Cannot say & No & Definitely not \\
\hline \multicolumn{5}{|c|}{ in different contexts } \\
\hline Definitely & Yes & Cannot say & No & Definitely not \\
\hline
\end{tabular}

Strategic- After starting to use Twitter, I have started using English more frequently in my communication \begin{tabular}{|l|l|l|l|l|}
\hline Definitely & Yes & Cannot say & No & Definitely not \\
\hline
\end{tabular} Strategic- I can plan my sentences in the English language, keeping in mind how the other person will understand it.

\begin{tabular}{|c|c|c|c|c|}
\hline Definitely & Yes & Cannot say & No & Definitely not \\
\hline \multicolumn{5}{|c|}{ Strategic- Due to the use of Twitter I can form full sentences in the English language } \\
\hline Definitely & Yes & Cannot say & No & Definitely not \\
\hline \multicolumn{5}{|c|}{ Sociolinguistic- I understand which words to use to express politeness in the English language } \\
\hline Definitely & Yes & Cannot say & No & Definitely not \\
\hline \multicolumn{5}{|c|}{ Sociolinguistic- I can write formal sentences in the English language } \\
\hline Definitely & Yes & Cannot say & No & tely not \\
\hline \multicolumn{5}{|c|}{ Sociolinguistic- I know how to communicate directly in the English language } \\
\hline Definitely & Yes & Cannot say & No & Definitely not \\
\hline \multicolumn{5}{|c|}{$\begin{array}{l}\text { Sociolinguistic- I understand somehow to use some words commonly used in English language but are not } \\
\text { actually part of the English dictionary. }\end{array}$} \\
\hline Definitely & Yes & Cannot say & No & Definitely not \\
\hline \multicolumn{5}{|c|}{$\begin{array}{l}\text { Sociolinguistic- I know what will be offensive to say to others in the English language and what will be } \\
\text { complementary to say. }\end{array}$} \\
\hline Definitely & Yes & Cannot say & No & Definite \\
\hline
\end{tabular}

